\title{
REZA NÃO É MÚSICA: A LAMENTAÇÃO DAS ALMAS NA CHAPADA DIAMANTINA
}

\author{
Carolina Pedreira ${ }^{1}$
}

\section{Introdução}

Rezas, cantigas, benditos e incelências ${ }^{2}$. No rastro dessas palavras, as aspirações etnográficas que originaram o presente trabalho sobre o ritual de encomenda dos mortos, também chamado de "lamentação" e "terno" das almas, chegaram até a Bahia, mais precisamente, na cidade de Andaraí, situada às margens do Rio Paraguaçu, ao sul da Chapada Diamantina ${ }^{3}$. A lamentação, alimentação ou encomendação das almas é uma espécie de penitência em que um grupo de pessoas, em sua maioria mulheres, sai pelos becos e ruas das cidades envoltas em lençóis brancos e, ao som da matraca ${ }^{4}$, realizam as estações (paradas), nas quais entoam preces, benditos e incelências como um coro polifônico em favor das almas. É um ritual tradicionalmente relacionado à formas mediterrâneas de lamentação, as quais teriam sido trazidas ao Brasil pelo colonialismo português, especialmente pelos missionários jesuítas. Deixando de lado a limitação originária, diremos apenas que se configuram como manifestações características do catolicismo popular, marcadas pela proximidade com religiões afro-brasileiras. É um rito lúgubre e, algumas vezes, demorado. Ainda que os ritos dessa natureza tenham existido em todas as regiões do país, o imaginário sobre a penitência está profundamente ligado a imagem do Nordeste, em detrimento de sua ocorrência em outros interiores do Brasil.

O imaginário sobre a penitência no Nordeste originou alguns escritos sobre manifestações similares e mesmo idênticas ao terno das almas na região da Chapada Diamantina. Uma delas é de autoria de Donald Pierson, que no Tomo III de sua compilação sobre O Homem no Vale do São Francisco, feita com base em uma vultosa pesquisa realizada em 1950, inscreve a lamentação como pertencendo aos

\footnotetext{
${ }^{1}$ Universidade de Brasília, Brasil.

2 Opto por grafar o termo "incelência" ao invés de "incelênsia", variante bastante comum, por se tratar de um regionalismo de "excelência", de acordo com o Dicionário Houaiss da Língua Portuguesa.

${ }^{3} \mathrm{O}$ presente texto é parte da dissertação de mestrado intitulada "Irmãs das Almas - Rituais de Lamentação na Chapada Diamantina" apresentada em março de 2010 ao Departamento de Antropologia da Universidade de Brasília. O trabalho de campo teve início em fevereiro de 2009 e seguiu pelo mês de março. Em abril, voltei à região para acompanhar a lamentação durante a Semana Santa, momento ápice da reza. Em novembro do mesmo ano, retornei a Andaraí para mais um mês de pesquisa.

${ }^{4}$ Instrumento composto de três pedaços de madeira unidos por uma corda, que produz um estalo forte ao ser movimentado para cima e para baixo.
} 
Rituais, cerimônias e crenças inicialmente introduzidos na região pelos portugueses, contudo, mesmo antes de ocorrida a fusão, em alguns casos, com formas culturais ameríndias e africanas, incluíam amiúde elementos de folk que variavam consideravelmente das formas urbanas ortodoxas. (Pierson, 1972:68)

A descrição do rito empreendida por Pierson é bastante próxima dos rituais realizados em Andaraí. O autor dedica, entretanto, poucas páginas a esse tópico, voltando-se para outras expressões da religiosidade local. Roberto Cunha (2002), em sua tese sobre o Rio São Francisco, cita a companhia de penitentes de Xique-Xique, na Bahia, os quais acompanham, durante a Quaresma, as 'alimentadeiras de almas' da cidade. É preciso, todavia, desvencilhar a reza das almas na Chapada Diamantina do tipo de penitência praticado, por exemplo, pelos 'cortadores' ou 'penitentes de disciplina' (Biancardi, 2006:201). No Estado da Bahia, a figura dos penitentes de disciplina está especialmente vinculada à cidade de Juazeiro, mas existem registros dessa prática nas regiões de Bom Jesus da Lapa, Cachoeira e mesmo em Lençóis, município vizinho a Andaraí. Os cortadores, que utilizam castigos corporais em suas peregrinações, também rezam benditos, tocam a matraca e realizam estações nos mesmos lugares habituais ao terno das almas. O autoflagelo, entretanto, está ausente em todos os relatos das rezadeiras e não há evidência de que, no passado, tivesse sido uma prática nas procissões da Semana Santa, como ainda acontece em Juazeiro e outros interiores do Nordeste

\footnotetext{
A penitência é uma prática religiosa muito antiga e foi uma maneira bem comum de atividade milenarista entre os séculos XIII e XIV. Nesses tempos medievais, a penitência era um ritual tradicional performado em procissões promovidas e organizadas pela Igreja Católica, que o prescrevia como uma forma de indulgência. No Brasil, esse tipo de ritual foi introduzido pelos primeiros missionários católicos, a quem se pode atribuir a inserção da forte tendência a crenças milenaristas e messiânicas entre os habitantes das regiões brasileiras mais isoladas e interiores, como ainda é, em certa medida, o sertão nordestino. (Campos, 2008:153).
}

Outra diferença a elucidar está na possível confusão das rezadeiras das almas com figuras igualmente comuns no interior nordestino: as carpideiras, mulheres cujo trabalho consiste em chorar a morte em velórios e funerais, entoando benditos e 
incelências ${ }^{5}$. Da mesma forma, não há indícios que os antecedentes da devoção no Brasil estejam ligados às irmandades ou confrarias (negras ou não), como a Irmandade da Boa Morte, fundada no século XVIII pelos nagô da nação queto em Salvador, cuja designação "evoca a relevância do ritual fúnebre para seus fundadores" (Reis, 2009:55). Todavia, ao longo da dissertação, veremos que existem tangências entre o cultos ancestrais praticados por escravos e ex-escravos e a permanência da devoção em Andaraí.

Em Andaraí, é Didé quem leva o terno adiante desde que a dona anterior, Dona Bete, teve sérias complicações de saúde. À dona do terno cabe tocar a matraca, conduzir as outras participantes pelos itinerários previamente escolhidos e determinados por alguém no passado e, principalmente, marcar o início e o fim a reza. Didé, que mais tarde tornou-se minha principal interlocutora e cuidadosa anfitriã, morava em uma comunidade rural antes de se mudar para a cidade. Conversamos pela primeira vez na salinha de costura de seu humilde ateliê, onde também vende, além das roupas e bolsas que faz, calçados, perfumes, bijuterias, brinquedos e gelo. Naquela tarde, Didé me convidou para participar do terno, que sairia na quarta-feira, cinco dias depois. Marcou o horário e pediu que eu arranjasse um lençol todo branco. Na primeira noite de reza, fui apresentada por Didé a Maura, Lôra, Miúda, Gracinha, Nadir, Edimarine, Idene, Suzana, Julieta, Maurina e Edite. Alguns desses nomes serão recorrentes no presente texto. Assim como os de Dona Véa de Cabuquina e Seu Vitalino, ambos grandes conhecedores da ciência da reza fora do circuito do terno comandado por Didé.

\section{A reza das almas}

A reza das almas é parte de uma devoção maior às entidades chamadas Almas Santas Benditas, que possuem, em termos funcionais e simbólicos, papéis semelhantes aos dos santos e das santas do panteão católico. É uma devoção, em termos nativos, fina. Pelo vínculo que as Almas Santas Benditas são capazes de realizar entre o mundo dos vivos e o dos mortos, pelo respeito que elas exigem em todas as situações em que são invocadas, a devoção as Almas Santas Benditas exige

\footnotetext{
${ }^{5}$ Referências imagéticas a essas personagens no Brasil podem ser encontradas nos filmes Deus e o Diabo na Terra do Sol (1964), de Glauber Rocha, e Abril Despedaçado (2001), de Walter Salles. No livro homônimo que inspirou a película de Salles, Ismail Kadaré descreve o doloroso choro das carpideiras da região do Rrafsh, na Albânia, as quais permanecem por horas ou dias com a face ensangüentada, depois de arranhá-la durante os velórios dos membros de seus clãs.
} 
lealdade e seriedade extremas. É preciso rezar todas as segundas-feiras, acender velas e sempre cumprir as promessas feitas a elas. As Almas, como são chamadas, são extremamente poderosas, porém severas. Quando se cumpre o dever de acender as velas das Almas Santas Benditas, elas concedem ao devoto o poder de vidência. A pessoa passa a ver o que quiser, especialmente em sonhos. Mas caso a pessoa falhe no compromisso, as Almas não a deixam dormir.

As "rezas de defunto", categoria em que estão inscritas as incelências na literatura sobre folclore e cantos populares, são definidas como "cantos de velório", uso atestado por Guilherme Santos Neves, citando o cânone do folclore brasileiro, Câmara Cascudo:

Os cânticos de velório ou rezas que se entoam, em coro, frente ao corpo frio do finado, noite e madrugada adentro, chamam-se excelências, palavra pernóstica que o povo simples suaviza em incelências. Lá está o verbete no Dicionário do folclore brasileiro, de Câmara Cascudo: "canto entoado à cabeceira dos moribundos ou dos mortos, cerimonial de velório ainda existente na Paraíba, Rio Grande do Norte e Pernambuco e possivelmente em outros Estados." (Neves, 2008:249-250, grifos do autor).

A reza das almas não deve ser confundida, entretanto, como ritual de "sentinela", este mais próximo da descrição feita por Neves. A sentinela, tal qual exposta por Ewelter Rocha (2006) em sua pesquisa no interior do Ceará, inicia-se com a morte ou quando é reconhecido que o indivíduo tem poucas horas de vida. A partir desse momento, chama-se um incelenceiro para puxar as rezas e os benditos. Em Andaraí, Edite, irmã da antiga dona do terno de Didé, Dona Bete, contou-me que era muito comum que se rezasse quando morria alguém na cidade ou nos arredores. $\mathrm{E}$ explicou que reza das almas é a mesma que se usava cantar ao velar um corpo “aquelas reza pesada, fica com o coração assim, pesado". A diferença é que o terno das almas, além de um luto anual pela Paixão de Cristo, é um luto por todos aqueles que já morreram.

O terno está inscrito em uma áurea de poder e severidade. Ele é constantemente descrito pelas mulheres que rezam ou rezaram em algum momento de suas vidas como uma responsabilidade grandiosa. Dona Lícia, que rezou por muitos anos no terno de Bete, em Andaraí, advertiu-me uma vez - "Se bulir com o terno, não está vivo". São muitas as histórias sobre pessoas que zombaram do terno ou jogaram pedra nas almas (como são chamadas as mulheres que rezam no terno pela 
população local) e passaram a ter visagens (visões de pessoas mortas), ficaram doentes ou mesmo morreram.

\section{Elementos e estrutura do ritual}

Em Andaraí, a reza das almas começa todos os anos na Quarta-feira de Cinzas. Ao longo da Quaresma, as saídas acontecem às segundas, quartas e sextas. $\mathrm{Na}$ Semana Santa reza-se todos os dias, completando a última saída na Sexta-feira da Paixão. Juntamente com as duas semanas anteriores, a Semana das Dores e a Semana das Trevas, esse período é considerado o mais importante da reza. Nessa cidade, as saídas são cumpridas sem falhas e somam vinte e um dias de reza, sendo que em cada um deles o trajeto é diferente. Cada dia de reza compõe-se de uma caminhada por algum lugar que começa ou termina em um ponto sagrado (igrejas, capelas, cruzeiros, cemitérios, encruzilhadas), ao longo da qual são realizadas sete estações (paradas), momento em que todas sentam, acendem as velas e iniciam o canto/reza.

Diz-se que a matraca acorda as almas, que chama os mortos, que avisa o momento da reza, como explica Dona Véa: “A matraca serve para espantar o que é ruim. Dizem que nos montes de Jerusalém, quando viram a matraca, o inimigo correu”. Guardar e manusear a matraca é uma incumbência da dona do terno, mas outras pessoas podem tocá-la durante a reza, no momento em que tiram o pai-nosso, como veremos a seguir. Quando uma das rezadeiras chega atrasada, depois de começada a reza na estação, deve-se, outra vez, tocar a matraca, como ensina Véa:

São três padre-nossos e são três benditos que se reza. E as velas ficam aí assistindo até acabar. Quando acabar, que sair, as velas ficam aí queimando e a gente vai embora. Aí a gente reza o que sabe, o que a gente souber, a gente reza. [...] É o que vier. Ali quando tira a incelência, o bendito, a matraca trabalha, avisa. Quando vem uma das que ficaram atrás, que não deu certo de ir junto com a gente, é vem embrulhada no lençol, a gente bate a matraca até a hora que ela chegar junto da gente.

Em cada estação, depois de nos sentarmos no chão ou na escadaria de uma igreja e acendermos as velas, a matraca, nas mãos da dona do terno, lança seu primeiro estalo. Em seguida, reza-se o primeiro bendito. Chamo de bendito-louvadoseja o primeiro bendito rezado na estação. O bendito de entrada, por sua vez, precede o bendito-louvado-seja e é rezado quando a estação começa na frente de igreja ou 
cemitério. Os dois benditos citados possuem um texto mais ou menos fixo em Andaraí.

A categoria "bendito", tende, na classificação nativa, a abarcar todos os tipos de reza, incluindo o bendito de entrada, o bendito-louvado-seja e os que, somente para tornar menos confusa a classificação, intitularemos de "benditos hagiológicos". Os benditos hagiológicos, chamados de benditos ou incelências, são rezas cantadas ou cantos rezados que versam sobre histórias de santos e santas, sobre a vida de Jesus, seu sofrimento na cruz, o padecimento e força de Nossa Senhora (e das muitas Nossas Senhoras), ressaltando agruras e/ou feitos heróicos dessas e outras entidades. Ainda que se estabeleçam grupos de rezas que se definem como benditos e outra, como incelências, no cotidiano da reza as duas palavras também são usadas com o mesmo sentido. Mais adiante, partiremos de uma análise dos elementos textuais das rezas com o intuito de nos aproximarmos dos elementos que conferem diferentes graus de "força de um bendito", uma noção nativa que, em linhas bastante gerais, remete à lembrança da Paixão de Jesus e do sofrimento de Maria.

Depois de rezado o primeiro bendito, segue-se as preces faladas em voz baixa: os pai-nossos, ave-marias e salve-rainhas. Cada grupo de preces é oferecido a um conjunto de almas específico. Na primeira e na última estações, tais ações, com exceção do coro que se segue ao solo, são exclusivas da dona do terno. Nas outras cinco estações o primeiro pedido também é feito pela dona. Nos outros três, as rezadeiras pegam a matraca e entoam os pedidos a alguns passos do grupo, como no exemplo:

Reze outro pai-nosso

Com a sua ave-maria, ô irmão das almas

Com a sua ave-maria, ô irmão das almas [coro]

Para toda aquelas almas

Das nossas obrigação, ô irmão das almas

Das nossas obrigação, ô irmão das almas [coro]

Reza, reza irmãos meu

Peço pelo amor de Deus, ô irmão das almas

Pra todos que já morreu, ô irmão das almas [coro]

Em Andaraí, os benditos (como o excerto transcrito acima) devem ser tirados por uma das mulheres no mesmo tom em que foi entoado o pedido, isto é, deve 
acompanhar a melodia do bendito-louvado-seja entoado pela dona do terno. Aos sussurros, as rezadeiras recitam as rezas oferecidas nos benditos: estão alimentando as almas. Ao final dos pedidos, reza-se primeira tríade de benditos hagiológicos. Outra vez, na primeira e na última estações, cabe à dona escolher, com base em um vasto repertório, qual bendito irá entoar. Nessa hora, as almas, que acompanham o terno em vigília, prostram-se, de joelhos, para receber as incelências. Nas demais estações, os três benditos são tirados pelas outras rezadeiras do terno. Ao final da primeira e última estações, deve-se entoar outra reza, chamada Senhor Deus, e ao final de cada estação, enquanto se levantam, dirigindo-se à próxima parada, há um pequeno cântico de despedida, tirado pela dona, o qual possui singelas variações também na estação que inicia e na que finaliza a lamentação:

\author{
Ô irmãos meu, fica com Deus \\ Que eu já me vou com Jesus Cristo \\ Eu já me vou com Jesus Cristo [coro] \\ Eu já me vou com Jesus Cristo \\ E o rosário de Maria \\ E o rosário de Maria [coro] \\ Acompanhado por essa noite \\ E amanhã por todo dia \\ E amanhã por todo o dia [coro]
}

O luto acaba na Sexta-feira da Paixão, quando as mulheres saem do cemitério e vão para a Igreja, rezar em cima do caixão de Senhor-Morto. A particularidade da saída nesse dia está no cântico de despedida tirado ao fimm das sete estações. Sendo a última noite do rito, entoar esse cântico especial em cada uma das paradas significa efetuar o desenlace dos lugares em que se realizaram saídas durante a Quaresma. Com essa reza, as mulheres pedem proteção às almas "até para o ano que vem", até o início de um novo ciclo do terno:

Despedida, despedida

Despedida de Belém, irmão das almas

De Belém, irmão das almas [coro]

Despedir das almas todas, até para o ano que vem, irmão das almas

$\mathrm{O}$ ano que vem, irmão das almas [coro]

Se algum de nós morrer, haveremos de encontrar, irmão das almas

De encontrar, irmão das almas [coro]

Haveremos de encontrar no Reino do Paraíso, irmão das almas

Do Paraíso, irmão das almas [coro]

No Reino do Paraíso, haveremos de encontrar, irmão das almas 
De encontrar, irmão das almas [coro]

Irmãos meus ficai com Deus

Que eu me vou com Jesus Cristo, irmão das almas

Com Jesus Cristo, irmão das almas [coro]

A despedida da Sexta-feira da Paixão, nome dado a esse canto, faz parte da categoria de rezas fortes no terno das almas. Segundo Maura, "Antigamente, a despedida, quem não tinha coração não agüentava não. A despedida é muito pesada”. À essa classificação, além dos benditos fortes, soma-se o Senhor Deus, uma reza que, como veremos, é poderosa dentro e fora do ritual.

\section{As almas}

Pontuados os principais elementos no contexto da reza, passaremos para uma pequena digressão sobre a noção de "almas", visto que elas são sujeitos de interlocução constantes não apenas no ritual de lamentação, mas em uma série de relatos das rezadeiras. Enquanto elementos centrais da devoção, as almas deslocam o terno de um rito religioso para um rito mágico, nos termos em que nos ensina Marcel Mauss. Ainda que, nas proposições do autor, seja difícil estabelecer fronteiras densas entre a religião e a magia, temos, em sua formulação das representações mágicas, as "almas dos mortos" - ou ao menos aquelas dotadas de "mana" - como a primeira categoria de espíritos mágicos. Nas palavras do autor,

Seres e coisas que são, por excelência, mágicos, são as almas dos mortos e tudo o que diz respeito à morte: testemunha-o o caráter eminentemente mágico da prática universal da evocação dos mortos [...]. Esses mesmos mortos são igualmente objetos dos ritos funerários, às vezes dos cultos de ancestrais nos quais se marca o quanto sua condição é diferente da dos vivos. (Mauss, 2003 [19021903]:153).

Na lamentação, sob a insígnia de "almas" são designadas todas aquelas que existem entre o mundo dos vivos e o mundo dos mortos. Nela também estão inscritas as Almas Santas Benditas. No presente texto, a referência às Almas Santas será feita por meio do "A" maiúsculo na inicial. Na ciência da reza, as Almas Santas Benditas eram almas ordinárias que foram salvas e santificadas. É desejado que se ofereça preces a elas em todas as saídas, pois constituem o grupo de maior poder dentre todas as almas. Qualquer alma, no universo da devoção, foi uma pessoa viva. Com a morte do corpo, as almas vão ser pesadas na balança de São Miguel: 
São Miguel é glorioso, pesador das alma santa

Pesador das alma santa

Essa alma aparecida, o que é que essa alma quer

O que é que essa alma quer

Deitei ela na balança, a balança não deu fiel

A balança não deu fiel

Os versos acima compõem a primeira parte do Bendito de São Miguel, um exemplo de bendito hagiológico do terno das almas. Considerado um bendito forte por Dona Véa, antiga rezadeira de Andaraí, nele temos a figura julgadora de São Miguel Arcanjo, a qual, na iconografia católica oficial, é representada como um anjo portando uma espada e uma balança e derrotando Lúcifer. O Arcanjo Miguel foi o líder das hostes de Deus contra o Anjo Caído e sua legião. A partir dessa batalha, recebeu o encargo de resgatar as almas boas na hora da morte, para que o Diabo não as corrompesse. Esse bendito traz a idéia de salvação das almas unida à um vocabulário muito comum à lida no garimpo. Ao deitar alma na balança, como deitar o diamante, o pino central, chamado "fiel”, torna-se a orientação máxima de seu valor. Quando a balança dá fiel, isto é, quando o pino se equilibra entre os dois pratos pendentes, a alma é santa, assim como se usava julgar o valor do diamante ao lado do peso de ferro. Com a morte, a alma, independente de quem tenha sido, deve passar por vários "processos", segundo Didé:

\begin{abstract}
A gente tem uma lenda de que a pessoa morre e vai passar no fogo. A alma tem que purificar no fogo do Inferno e tem vários processos pra chegar a Alma Santa Bendita. Quem fez boas camas tem os processos, mas chega num lugar bom. Diz que um anjo, se o menino acabou de nascer e morreu morto, diz que só pelo leite ou por a gente pegar nele, já tem que passar nesse fogo. E a vida continua. Dizem que a vida continua. Ninguém espera mudança. Se você faz de tudo bom aqui na Terra, lá você vai ser a mesma coisa. E quem faz ruim, vai continuar no mesmo.
\end{abstract}

Tais processos podem durar por toda a eternidade. Isso acontece com as almas que estão em aflição. São elas, por exemplo, as almas dos suicidas e das pessoas avarentas, as quais tendem a ficar muito tempo ardendo no fogo do Purgatório. Contudo, às almas está sempre aberta a possibilidade da salvação. Elas não são definitivamente boas ou más. Os processos incluem jogos que movimentam as 
relações entre pessoas vivas e mundo dos mortos. Nessa explicação dada, outra vez, por Didé, temos uma das fundamentações para a reza das almas:

Dizem que quando uma alma vem aparecer para gente, que a gente tem medo, não é ela que vem meter medo, é que ela está acompanhada com o inimigo. Então o inimigo vem na frente fazendo toda aquela latomia na presença daquela pessoa. Porque aí ela vem no jogo, se chegou e encontrou palavra boa, ela ganha a luta. E se ela achou uma palavra ruim, ela perde. Não é a alma, ela ali não tem nada a ver com aquilo. Ali, vamos supor, ela está na pendência. Aí se chegou, a pessoa é forte, rezou para ela, fez alguma coisa, o demônio perde a luta. E ela se livra. Agora se chegou, como tem gente que fala - "Ah, vai pro inferno!" - aí pronto. Ele ganhou a luta.

De acordo com os imperativos da devoção, deve-se sempre rezar pelas almas que estão em aflição e para as almas abandonadas, as que não tem ninguém por elas. Por isso, é importante, na Sexta-feira da Paixão, mais do que no dia de Finados, ir ao cemitério acender velas nas carneiras (túmulos), pois não se sabe se aquela alma será lembrada por alguém. As almas das nossas obrigação referem-se, via de regra, aos parentes mortos e aos que, em vida, foram devotos das almas. Também é designada assim alguma outra alma desconhecida com a qual a pessoa possui uma ligação por meio de vidas passadas, ligações que não são facilmente explicáveis. Mesmo sem saber ao certo quem foi essa alma no passado, a devota entende que ela é da sua obrigação, pois a ela se dirige em muitos dos seus pedidos e, por conseguinte, no oferecimento das rezas. De acordo com Didé, no cotidiano das relações entre vivos e almas, existem também algumas precauções a serem tomadas:

\footnotetext{
[Passar por uma cerca de] Arame geralmente abre o corpo. Arame e sentar em porta que você toma o espaço todo. Eu mesmo já sento, mas não é certo. Porque hoje nós vivemos no mundo dos espíritos. Só que a gente sabe e não dá muita importância. Mas eu acho que o mesmo tanto que gente que tem morto, tem vivo. Tem vivo, tem morto. Então nós estamos aqui e não sabemos quantos estão passando aqui, pra lá e pra cá. Então aí você senta na porta, tomou a passagem. Então, quem vem de lá pra cá, passa por cima. Se for um bom, acabou. Se for um ruim, já não é bom a gente estar deixando, né? E o arame abre o corpo. Qualquer coisa que você tiver para fazer, você tem suas defesas, mas você passou ali debaixo do arame, não pode. Dizem que as duas coisa piores são arame e porta.
}

$\mathrm{Na}$ reza, as almas estão diretamente vinculadas aos espíritos que constituem parte do universo dos encantados no jarê. Bater jarê, bater couro e sambar são 
sinônimos da participação em um culto que se aproxima ora do candomblé, ora da umbanda, sobre o qual se diz que só existe, com esse nome, na Chapada Diamantina. A partir das próximas linhas, aparecerão, volta e meia, indícios da profunda relação entre o terno e o jarê. Por enquanto, nossa intenção é situar o leitor, ainda que de forma sumária, em um mundo que será constantemente citado pelas mulheres em Andaraí.

\section{Notas sobre o Jarê}

O jarê parece ser uma variante do chamado "candomblé de caboclo", no qual se incluem os cultos de catimbó e jurema no Nordeste. Nesses últimos, todavia, a presença das religiões de matriz africana está em segundo plano quando comparadas à centralidade de entidades indígenas e do profundo conhecimento das ervas por parte dos mestres. O jarê, por outro lado, "representa uma vertente menos ortodoxa do candomblé, resultante de um complexo processo de fusão, no qual à influência dos cultos Bantu-Yoruba, sobrepuseram-se elementos do catolicismo rural, da umbanda e do espiritismo kardecista.” (Alves e Rabelo, 2009:2). Nesse culto, os orixás foram assimilados em uma classe genérica de "espíritos" ou "guias": os caboclos (invocados da aldeia sagrada de Aruanda), os nagô e os pretos-velhos (Carvalho, 1996:164). Em Andaraí, os guias nagô são individualizados nas figuras de alguns orixás, tais como Oxum, Iansã, Xangô e especialmente, Ogun. As categorias de guias, espíritos e caboclos e encantados são usadas como termos gerais para se referir a todas as entidades do jarê. Meu primeiro convite para ir a um samba foi feito por Didé uma semana depois do início da reza das almas:

Então pronto, vai ser mais divertido que as almas, que não vai ter choro, a não ser que você tenha alguma coisa que te faça chorar. Vai saber, né? Vai ter a feijoada do vaqueiro. E depois a gente samba a noite toda. Aí bate couro, a gente samba, a gente dança, veste assim de baiana. É muito divertido. Lá a gente faz com pouca gente, mas a gente se diverte do jeito da gente.

O jarê para o qual fui convidada a participar é freqüentado por muitas das mulheres que rezam no terno em Andaraí: é o jarê de Carmosa. Carmosa é curadeira e participa do terno das almas de forma irregular, apesar da forte ligação que possui com Didé. Curador e curadeira são títulos usados para designar pessoas que exercem a função de líderes espirituais e que, geralmente, são donos ou donas de casa de jarê. 
Tais pessoas podem ter um lugar fixo onde realizam trabalhos ou serem espécies de profetas nômades, realizando festas, batismos e consultas pessoais em diferentes cidades. Maurina, uma das rezadeiras do terno de Didé, é ogan no jarê de Carmosa. Foi Didé quem primeiro a levou para o jarê, depois de muita resistência. Há cerca de quinze anos atrás, Maurina, que passava por sérios problemas com o marido e os filhos, começou a incorporar caboclos dentro de casa. No início, conta Didé, foi difícil convencê-la de que era preciso trabalhar seus encantados, isto é, cumprir com as obrigações que Maurina tinha com os caboclos. Hoje, ela ocupa o segundo posto de mais prestígio no jarê de Carmosa. Já no terno, Maurina não tira pai-nosso e sua voz grave, segundo Didé, pouco se destaca na reza:

No jarê, na hora que elas incorporam, que aí gente que não sabe, na hora que incorpora, eu digo - "Mas meu filho, fica só olhando!". Maurina sem nada ela não faz nada, você vê, ela não tem voz, ela não sabe nada. Mas na hora que dá ponto, vira um canarinho na arapuca! Eu digo - "É, está certo".

Em outros cultos, o termo ogan se refere àquele que toca o atabaque, mas no jarê de Carmosa, essa denominação é dada à figura que auxilia a curadeira. O responsável pelo atabaque é Calango, esposo de Carmosa. Didé executa algumas atividades tradicionalmente atreladas às equedes na hierarquia feminina do candomblé, amparando a curadeira e a ogan durante a incorporação. Contudo, sua relação com o culto, embora seja forte, é demasiado fluida para se habilitar a esse tipo de classificação.

Os rituais do jarê, de forma geral, podem ser divididos em "festas" e "trabalhos". Nas festas ou sambas, qualquer pessoa que esteja visitando a casa pode participar. O samba começa morno, com os atabaques sendo tocados por iniciantes e duas ou três mulheres rodando suas saias de baiana em um salão enfeitado com bandeirolas, quadros de Santa Bárbara, de São Sebastião e algumas imagens de pretos-velhos. Em pouco tempo, Calango assume o batuque e, conforme a linhagem dos caboclos vão sendo chamadas por meio dos pontos e cantigas, o salão torna-se repleto de senhoras, moças e crianças rodando suas saias coloridas. Muitas dessas festas são feitas em comemoração a algum santo. Na primeira noite em que sambei no jarê, a festa era a feijoada do vaqueiro. Essas datas estão ligadas ao tipo de comida que se oferece ao santo e aos jarezeiros: na tradicional festa de São Cosme e Damião ou Dois-Dois, em 27 de setembro, dá-se o vatapá e o caruru (ou cariru) às crianças de 
dia e samba-se para o caboclo à noite, outra vez, com a mesa para o santo. Outro samba tradicional é o de Santa Bárbara/Iansã, realizado em dezembro, na qual também se oferece o caruru. Além dessas festas, cada curador estabelece o próprio calendário com rituais de honra a seus guias. Em Andaraí, o caruru de São Cosme e Damião é uma festa que não se restringe ao jarê e durante todo o mês de setembro, várias pessoas oferecem o caruru para as crianças.

Os trabalhos, por seu turno, são rituais de cura, às vezes, públicos e, outras, privados. Mesmo quando são abertos, os trabalhos visam atender a alguma aflição vivida por um indivíduo, seja ele de dentro da casa ou alguém que tenha procurado a curadeira com esse intuito. As aflições são doenças físicas e/ou espirituais que acometem uma pessoa, sendo, via de regra, causadas por feitiços, como um quebranto ou mesmo outro trabalho. Ao contrário da festa, em que ocorrem séries de incorporações, no trabalho apenas a curadeira e, algumas vezes, a ogan, recebem seus caboclos, dessa vez sem dança e sem batuque, mas com cantigas e rezas:

O trabalho se inicia com cantos a Exu para que conceda licença a atividade de cura e comprometa-se a guardar as encruzilhadas, porteiras e cancelas que conduzem ao terreiro. Mais tarde oferendas são feitas a Exu e depositadas em sua casa nos fundos do terreiro. O tema da expulsão de agentes causadores da doença ganha expressão durante a performance que se segue: o curador introduz uma série de cânticos em que nomeia distintos poderes responsáveis pela doença (exus, sombras de morto) chamando-os a deixar o corpo do doente. Mudanças no comportamento do doente durante este processo atraem grandemente a atenção da audiência na medida em que confirmam a realidade construída pelo curador. (Alves e Rabelo, 2009: 10-11)

Ao final do trabalho, a pessoa doente deve permanecer sob os cuidados do curador ou curadeira por um período de sete dias a um mês. Antes de cada trabalho, deve-se dançar no salão, dedicando cantigas aos caboclos, tendo em vista que eles possuem um poder ambíguo: são capazes de, no mesmo indivíduo, curar a doença e causá-la (ibid.: 12). Essa causalidade, entretanto, não é gratuita, possui, antes, relação direta com a entrada de uma pessoa no jarê. Os rituais de cura servem para iniciar o indivíduo no culto e, caso ele se negue a continuar cumprindo com as obrigações que possui com o caboclo, cedo ou tarde, acabará por voltar para a casa do curador ou curadeira para outro trabalho. Em Andaraí, ciclos dessa natureza foram várias vezes descritos pelas mulheres com as quais convivi. Ali, parafraseando um comentário de Maura, quem ainda não foi ao jarê, com certeza irá, seja católico, crente ou espírita - 
“e quem diz que não vai é porque já foi”.

\title{
Os benditos
}

Os benditos e incelências do terno das almas mereceriam um texto exclusivo, dada a centralidade de sua presença na reza. O que será apresentado nessa sessão diz respeito apenas a uma breve aproximação às suas variações e conteúdos. Acima, vimos que a categoria "bendito" se estende a todas as rezas entoadas no terno, quais sejam: o bendito de entrada, o bendito-louvado-seja e os que, para tornar mais clara a descrição, chamamos de "benditos hagiológicos", termo inexistente na classificação nativa. Os textos dos dois primeiros são relativamente fixos. Os benditos hagiológicos, por sua vez, são divididos, quanto às suas características poéticotextuais, em quatro classes:

(i) aqueles que se compõem de uma cadência de diferentes versos que podem ou não se repetir, caracterizando-se pela ausência de estribilho;

\author{
$\mathrm{Na}$ Quinta-feira Santa \\ Apareceu uma imagem \\ A Quinta-feira Santa \\ É três dias antes de Páscoa \\ O Redentor chegou \\ Os seus discípulos foi chamado \\ Com a cruz maior nas costas \\ E um madeiro muito pesado \\ Cada passada que dava \\ Gota de sangue suava \\ Caía nas três marias \\ E uma era Madalena \\ Uma cruzava os pés \\ E a outra enxugava o rosto \\ E a outra recordava \\ Do sangue que Jesus lançou \\ Cada pingo que pingava \\ Era a hóstia consagrada \\ Todos homens que bebiam \\ Eram bem-aventurados \\ Neste mundo era um rei \\ E no outro era um rei coroado \\ Ofereço essa oração pro Senhor que está na cruz \\ À paixão do Redentor \\ Para sempre, amém Jesus
}


(ii) os que se compõe de versos na primeira parte, repetindo-se o último, seguidos de um estribilho na segunda parte, continuando com a alternação de diferentes versos e o mesmo estribilho;

Levantei de madrugada

Sexta-feira da Paixão

Sexta-feira da Paixão

Encontrei Nossa Senhora

Com seu rosário na mão

Com seu rosário na mão

Nossa Senhora bem disse

Que haverá de nos deixar

Que haverá de nos deixar

Eu dei o rosário a ela

Ela me disse - Pois não

Ela me disse - Pois não

Nossa Senhora bem disse

Que haverá de nos deixar

Que haverá de nos deixar

E me deu um lindo terço

De todo seu coração

De todo seu coração

Nossa Senhora bem disse

Que haverá de nos deixar

Que haverá de nos deixar

O terço que ela me deu

Chamou-me muita atenção

Chamou-me muita atenção

Nossa Senhora bem disse

Que haverá de nos deixar

Que haverá de nos deixar

Para compreender os mistérios

Da divina encarnação

Da divina encarnação

Nossa Senhora bem disse

Que haverá de nos deixar

Que haverá de nos deixar

Quem contempla este mistério

Com seu joelho no chão

Com seu joelho no chão

Nossa Senhora bem disse

Que haverá de nos deixar

Que haverá de nos deixar

Nesse mundo ganha um prêmio

E no outro a salvação

No outro a salvação

Nossa Senhora bem disse

Que haverá de nos deixar

Que haverá de nos deixar

Quem segura este rosário

Segura o mundo nas mãos

Segura o mundo nas mãos 
Nossa Senhora bem disse Que haverá de nos deixar Que haverá de nos deixar Pra tirar os seus devoto Do caminho da perdição Do caminho da perdição Nossa Senhora bem disse Que haverá de nos deixar Que haverá de nos deixar Nossa Senhora pediu Para toda a multidão Para toda a multidão Nossa Senhora bem disse Que haverá de nos deixar Que haverá de nos deixar Volta pra seu bento filho Por meio da confissão Por meio da confissão Nossa Senhora bem disse Que haverá de nos deixar Que haverá de nos deixar Ela pediu pra seus filho Viver todo em comunhão Viver todo em comunhão Nossa Senhora bem disse Que haverá de nos deixar Que haverá de nos deixar E a São Pedro e São Carlos

São Tiago e São João

São Tiago e São João

Nossa Senhora bem disse

Que haverá de nos deixar Que haverá de nos deixar Ofereço esse bendito A virgem da Conceição A virgem da Conceição Nossa Senhora bem disse Que haverá de nos deixar Que haverá de nos deixar Ó meu Bom Jesus da Lapa Filho de Deus e de Abraão Filho de Deus e de Abraão Nossa Senhora bem disse Que haverá de nos deixar Que haverá de nos deixar

(iii) os que se referem, na primeira parte, aos dias da Semana Santa, ao Sábado de Aleluia e ao Domingo de Páscoa, seguindo-se de um estribilho fixo na segunda parte, continuando com a seqüência dos dias, intercaladas pelo mesmo estribilho; 
Jesus Cristo ajoelhava

Do açoito que lhe dava

Jesus Cristo ajoelhava

Do açoito que lhe dava

Faz três dias que eu ando

Atrás do filho da Virgem Maria

Ó que pranto doloroso

O pranto da Virgem Maria

Ó que pranto doloroso

O pranto da Virgem Maria

Na Terça-feira Santa

No empino de mei-dia

Jesus Cristo ajoelhava

Do açoito que lhe dava

Jesus Cristo ajoelhava

Do açoito que lhe dava

Faz três dias que eu ando

Atrás do filho da Virgem Maria

Ó que pranto doloroso

O pranto da Virgem Maria

Ó que pranto doloroso

O pranto da Virgem Maria

Na Quarta-feira Santa

No empino de mei-dia

Jesus Cristo ajoelhava

Do açoito que lhe dava

Jesus Cristo ajoelhava

Do açoito que lhe dava

Faz três dias que eu ando

Atrás do filho da Virgem Maria

Ó que pranto doloroso

O pranto da Virgem Maria

Ó que pranto doloroso

O pranto da Virgem Maria

$\mathrm{Na}$ quinta-feira santa

No empino de mei-dia

Jesus Cristo ajoelhava

Do açoito que lhe dava

Jesus Cristo ajoelhava

Do açoito que lhe dava

Faz três dias que eu ando

Atrás do filho da Virgem Maria

Ó que pranto doloroso

O pranto da Virgem Maria

Ó que pranto doloroso

O pranto da Virgem Maria

$\mathrm{Na}$ Sexta-feira Santa

No empino de mei-dia

Jesus Cristo ajoelhava

Do açoito que lhe dava

Jesus Cristo ajoelhava

Do açoito que lhe dava

Faz três dias que eu ando

Atrás do filho da Virgem Maria

Ó que pranto doloroso 

O pranto da Virgem Maria
Ó que pranto doloroso
O pranto da Virgem Maria
No Sábado da Aleluia
No empino de mei-dia
Jesus Cristo ajoelhava
Do açoito que lhe dava
Jesus Cristo ajoelhava
Do açoito que lhe dava
Faz três dias que eu ando
Atrás do filho da Virgem Maria
Ó que pranto doloroso
O pranto da Virgem Maria
Ó que pranto doloroso
O pranto da Virgem Maria
No Domingo da Ressurreição
No empino de mei-dia
Jesus Cristo ajoelhava
Do açoito que lhe dava
Jesus Cristo ajoelhava
Do açoito que lhe dava
Faz três dias que eu ando
Atrás do filho da Virgem Maria
Ó que pranto doloroso
O pranto da Virgem Maria
Ó que pranto doloroso
O pranto da Virgem Maria

(iv) aqueles geralmente chamados de "incelências", nos quais se repetem os mesmos versos em uma série de um até sete, repetindo também um mesmo estribilho, finalizando até tantos:

\footnotetext{
Uma incelência da Virgem, Senhora é da Soledade

Ela é a nossa mãe bendita, ela é dolorosa, ela é imaculada \} ESTRIBILHO 2X

Duas incelências da Virgem...

até

Tantas incelências...
}

Os benditos transcritos são um pequeno exemplo do vasto repertório que encontrei em Andaraí. Os benditos mais fortes versam, geralmente, sobre o sofrimento de Cristo e são rezados de forma ainda mais lamentosa pelas mulheres, entre suspiros e, vez ou outra, algumas lágrimas. O primeiro exemplo é o Bendito da Paixão, que não foi rezado em nenhuma das saídas de 2009, pois Dona Véa, a única que sabe entoá-lo do começo ao fim, não pôde rezar nesse ano. O segundo é chamado de Mistério de Nossa Senhora e o terceiro, de Pranto da Virgem, dois dos benditos mais fortes rezados em Andaraí. Ambos são de execução exclusiva de Didé. O último 
exemplo, a Incelência de Nossa Senhora da Soledade é um bendito mais comum, como todos os que se classificam como incelência de um santo ou santa específicos. Todavia, algumas incelências podem ser mais fortes que outras. Nesse caso, as rezas perdem o lastro de incelência e passam a ser chamadas de benditos. Para isso, seu texto deve ter como tema a paixão de Cristo ou o sofrimento de Nossa Senhora, como o Bendito de Nossa Senhora das Dores, cuja forma se aproxima mais do exemplo tipificado em (iii) do que da incelência transcrita em (iv):

Foi na primeira dor

Foi quando a Senhora estava

Com seu filho Morto

Coroada de flor

Bendita sejais, ô Senhora das Dor

Cercada de anjo

Coroada de flor

Foi na segunda dor...

A categoria de força de um bendito está intimamente ligada a sua estrutura poética, captada na ligação intrínseca entre som e do sentido. Nos quatro tipos de benditos descritos, percebemos a predominância de estruturas paralelísticas que garantem não apenas uma cadência rítmica, mas a relação entre palavras e idéias que se repetem para além da presença da rima, isto é, garantem uma equivalência de som que, projetada na seqüência, envolve equivalência semântica (Jakobson, 1971:368). O fundamental na percepção dessa relação é a de que, na tipificação empreendida, os benditos considerados mais fortes pelas rezadeiras são os que se definem em (i), (ii) e (iii), nos quais percebemos uma quantidade maior de palavras semelhantes no som e diferentes no sentido (paranomásia), quando comparados com o definido em (iv).

A centralidade do texto musical na teoria nativa sobre a eficácia - a noção de força de um bendito - alarga a compreensão dos benditos como fórmulas mágicas cuja intenção seria apenas prolongar a comunicação (privilégio da função fática), no caso, com as almas, para, sobretudo, um foco contínuo sobre a mensagem transmitida (privilégio da função poética). Estamos, nesse marco, no campo sobre o qual nos fala Jakobson em sua compreensão da hierarquização das funções da linguagem (cf. Jakobson 1971) nos atos de comunicação verbal, os quais ele nomeia como eventos de fala (speech events). A poética musical nessa categorização dos benditos mostra, com clareza, a sobreposição da similaridade sobre a contigüidade em um nexo entre som e significado (sound-meaning nexus) criado pela efusão de paranomásias em uma 
textura sonora na estrutura poética e na comunicação mágica. Veremos agora como essa comunicação se articula junto aos recursos individuais da toada.

\section{As toadas}

A literatura acerca de rituais de lamentação em várias partes do mundo está fortemente vinculada aos estudos etnomusicológicos de ritos mortuários em populações indígenas, como os Warao na Venezuela (Briggs, 1993), os Kaluli na Papua Nova Guiné (Feld, 1982) e uma análise comparativa do "choro ritual" entre o Xavante, os Bororo e os Xokleng (Urban, 1988). A esses trabalhos, somam-se àqueles sobre cantos fúnebres em populações tradicionais de algumas regiões do mediterrâneo, especialmente na Grécia (Alexiou, 1974; Caraveli-Chaves, 1980), e em países como a Finlândia (Tolbert, 1990) e a Irlanda (Lysaght, 1997). Uma das questões centrais nesse marco temático é a fronteira confusa entre fala e música: entre a palavra falada e os sons musicais. A dificuldade em estabelecer uma classificação para os sons nesses rituais é também índice da profunda relação entre música e morte e do tipo de intermediação que se dá entre o mundo dos vivos e o mundo dos mortos ao entoar determinados sons.

A tensão entre palavra falada e palavra cantada nos rituais de lamentação é um ponto nodal da análise não apenas da dimensão estética, mas da profunda ligação entre os estilos de lamentação ao redor do mundo e os discursos das mulheres acerca da morte, da perda e da dor. Essa tensão parece remeter à compreensão da lamentação como espaços-tempos de produção de relações de solidariedade/resistência entre grupos de mulheres (Feld e Fox, 1994). Para além da análise dos repertórios musicais da lamentação, é mister uma aproximação à performance das emoções, costuradas fio a fio tanto nas palavras cantadas quanto na teoria nativa. Entretanto, essa é uma aproximação delicada, cuja armadilha comum acaba se tornando uma prerrogativa nas análises de rituais de lamentação: a universalização dos significados culturais de tristeza e de luto e da própria experiência da morte. Uma definição usada pelas lamentadeiras da Carélia ${ }^{6}$ e recuperada no estudo de Elizabeth Tolbert (1990) nomeia a lamentação como o "choro com palavras" (cry with words) - o choro ritualizado, em

\footnotetext{
${ }^{6}$ A Carélia é uma região partilhada pela Finlândia e pela Federação Russa. A Carélia Finlandesa engloba as províncias da Carélia do Norte e da Carélia do Sul. A parte russa é constituída pela República Autônoma da Carélia, que abrange o território entre o mar Branco e a Olonets Carélia, e as regiões do istmo da Carélia e Ladoga Carélia. O estudo de Elizabeth Tolbert foi realizado na porção finlandesa entre os anos de 1984 e 1985.
} 
contraposição ao "choro com os olhos" (cry with the eyes) dos homens - o chorar comum. A atenção de Tolbert está centrada nos parâmetros de interação que levam a lamentação de uma expressão voluntária de sentimentos a uma simbolização dos afetos.

O "choro com palavras" das lamentadeiras carelianas me faz pensar que os benditos entoados no terno das almas são "choros com rezas". A reza das almas é, nas três localidades estudadas, plena de elementos musicais. Os benditos do terno se aproximam da definição de benditos fúnebres dada por Ewelter Rocha em seu estudo sobre as sentinelas do Cariri, no Ceará:

O uso da música religiosa do catolicismo popular do Cariri está geralmente associado a práticas religiosas, o que torna, para os praticantes, mais tênue a separação entre música e reza. Iniciando a distinção, observemos a aplicação do termo "reza" no cotidiano religioso caririense. A acepção deste termo não está unicamente associada a uma prece falada, mas engloba também o repertório musical de cunho religioso. A utilização de expressões como "rezar um bendito", "rezar uma incelença", "rezar cantando", ilustra a conotação musical conferida ao vocábulo. Por outro lado, expressões do tipo "rezar o Pai-Nosso", "rezar a Ave-Maria" ressaltam a utilização mais comum do termo, associando-o a uma prece falada. (Rocha, 2006:58).

$\mathrm{Na}$ estrutura do rito na Bahia, há uma divisão semelhante, marcada pela diferença entre pedir/tirar um pai-nosso (ao entoar: "Reze outro pai-nosso, com a sua ave-maria, irmão das almas"), que corresponde à parte cantada, e o momento seguinte, que compreende o próprio ato de realizar as preces faladas aos sussurros, sem cantos. A preces são o único elemento falado do terno, tendo em vista que a primeira estação inicia-se com um bendito, seja o de entrada, se for realizada em frente a um cemitério ou igreja, seja o bendito-louvado-seja. Abaixo, apresento o conteúdo musical e textual dos dois benditos citados na forma como são rezados em Andaraí. A voz principal é executada por Didé e a segunda voz, que sobressai em benditos específicos, por Miúda. O coro segue a mesma melodia da voz principal:

\section{Bendito de Entrada}



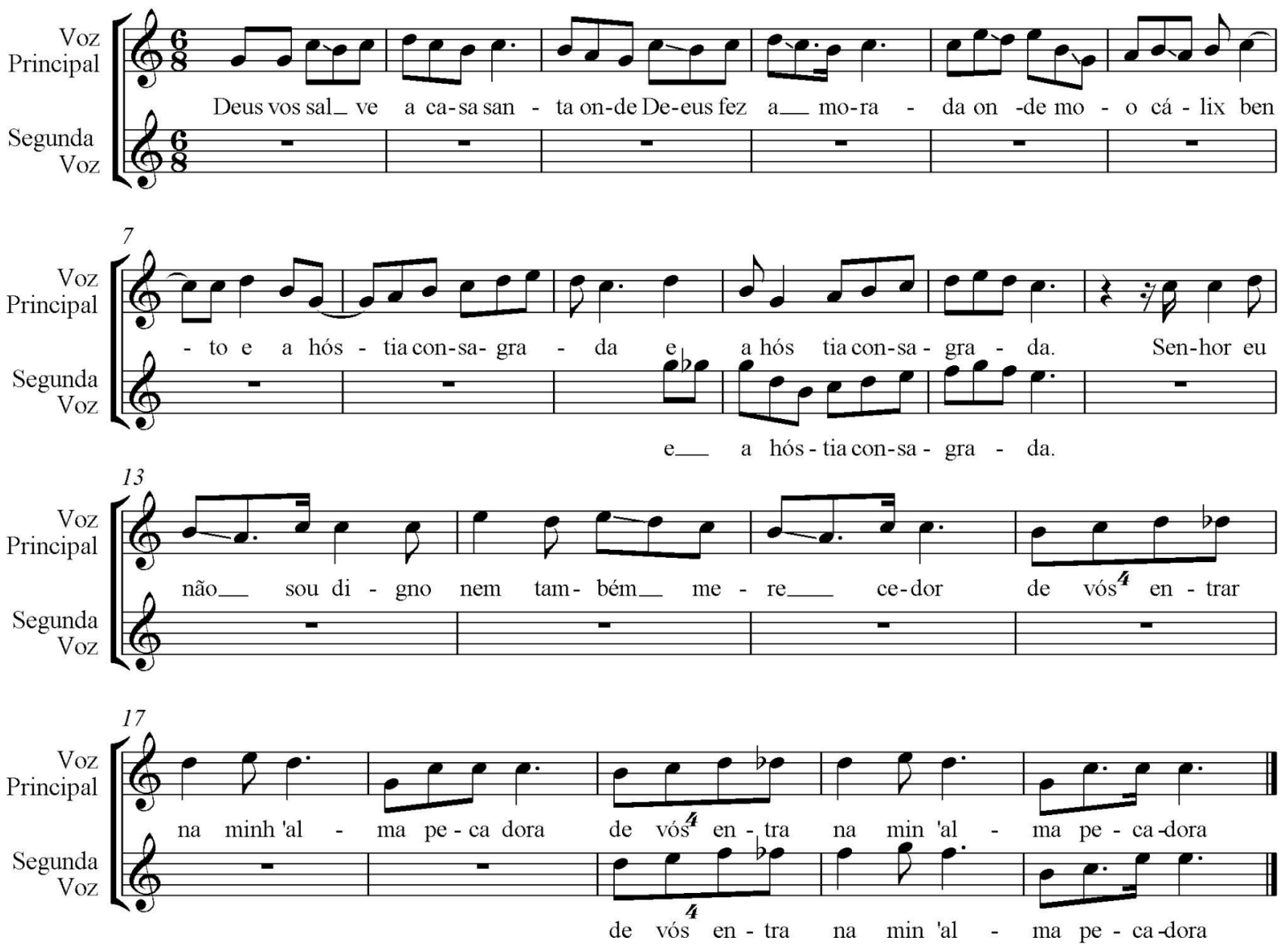

II. Bendito-louvado-seja
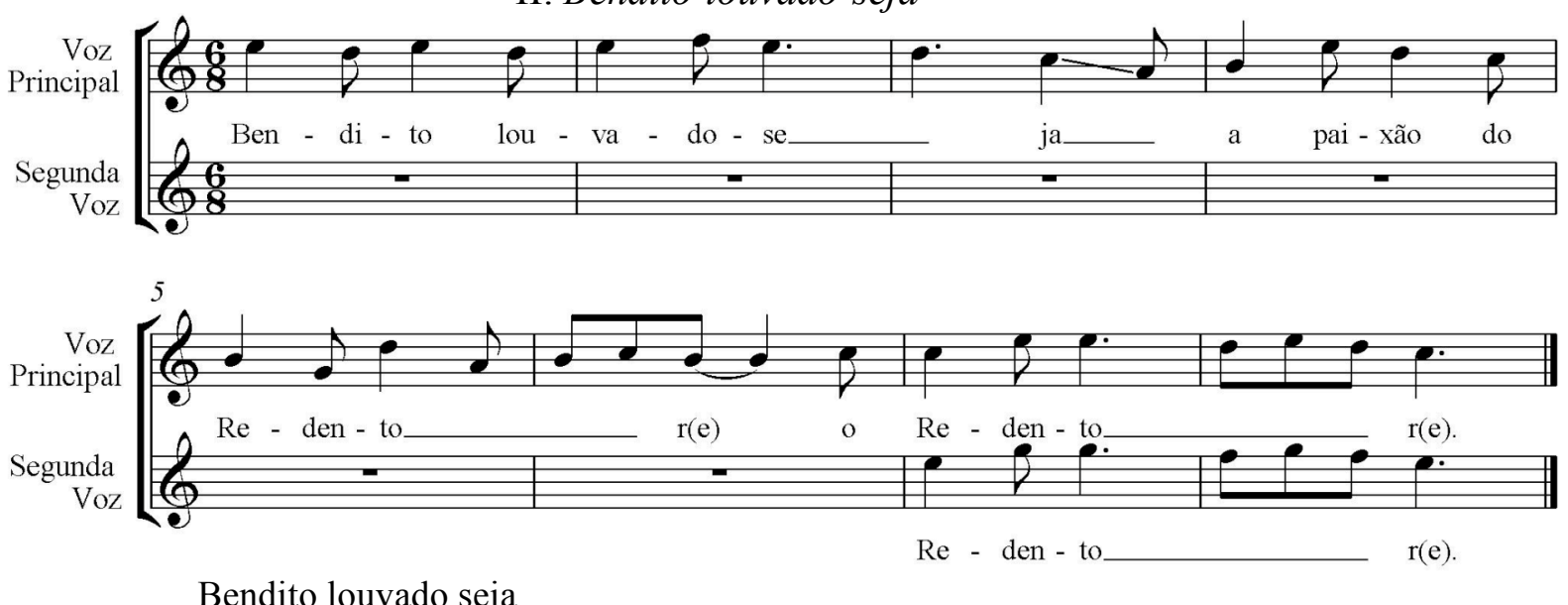

Bendito louvado seja

A paixão do Rendentor

Do Redentor

Que desceu dos céus a terra 
Padeceu por nosso amor

Por nosso amor

Padeceu grandes tormentos

Trabalhou penas e dores

Penas e dores

Derramou seu bento sangue

Pra remir aos pecadores

Aos pecadores

Irmão meus que está acordado

Acordai quem está dormindo

Quem está dormindo

Pra rezar um pai-nosso

Com a sua ave Maria

Ave Maria

Para toda aquelas almas

[...]

Nos exemplos transcritos, a linha melódica do primeiro é fixa, o que significa que ele será entoado sempre da mesma maneira. O segundo bendito, por sua vez, é entoado nessa melodia apenas quando sucede o bendito de entrada. Em termos nativos, essas variações musicais do bendito-louvado-seja são denominadas toadas e representam o componente ritual mais marcante do terno de Andaraí. É de incumbência exclusiva da dona do terno estabelecer em que toada será tirado o bendito-louvado-seja, e, conseqüentemente, o primeiro conjunto de pai-nossos, avemarias e a salve-rainha de cada uma das sete estações. Nas primeira e última estações, ela é também responsável por entoar os benditos hagiológicos (um ou três), conforme descrito no item anterior. Para cumprir com essas tarefas e, ademais, estar atenta aos erros de execução das outras participantes, a dona do terno precisa conhecer o extenso repertório de benditos e dominar os recursos musicais das toadas. Em cada uma das cinco estações em que a dona não tira o pai-nosso (mas dá toada), uma pessoa se desgarra do grupo, anda alguns passos à frente, pede o pai-nosso e toca a matraca durante as preces. Sobre a fronteira entre reza e canto no terno, Didé explica:

Eu: O terno é cantado ou rezado?

Didé: São as rezas, só que cantadas. É reza, não é música. É reza mesmo. A gente reza pai-nosso, reza salve-rainha. Mas ali tudo já tem aquele tom que você reza e pede os outros para rezar naquele tom certo. [...] Têm muitas toadas de benditos e muitos benditos.

No terno, as toadas são a forma certa de rezar para os mortos - errando a toada, a comunicação falha. Conseguir tirar um bendito na toada em que se tirou o pai-nosso significa estar atento ao momento do ritual e, acima de tudo, "saber rezar". 
O perfeito encadeamento da toada com o pai-nosso requer concentração, habilidade e boa voz. Ter boa voz significa conseguir alcançar diferentes alturas nas toadas. Não há, todavia, uma classificação, até onde pude perceber, de boa voz como uma voz bela. Existem toadas mais fáceis, costumeiras, e outras difíceis, nas quais algumas pessoas se embaralham em meio à melodia ou em rápidas variações de altura. Entretanto, há aqueles que ignoram essa máxima e tiram o bendito em outra toada. Quando isso ocorre, rompe-se a ligação entre vivos e mortos por via das Almas Santas Benditas. Algumas toadas são tiradas para uma pessoa específica como forma de evitar a incidência desse rompimento e/ou de fortalecer a presença de uma das rezadeiras no terno.

Em um grupo que chega a ter, no máximo, vinte pessoas na Semana Santa, existe um núcleo diretamente ligado a Didé e fiel à reza - que chamarei de "núcleo devoto" - e outro flutuante, composto de cerca de cinco mulheres cuja devoção é questionada pelo primeiro grupo devido à constante ausência nos ritos e dois homens, Zé e Messias, que rezavam no terno quando Bete ainda o conduzia, os quais estão envolvidos com intrigas que desafiam a liderança de Didé. No terno de Andaraí, mesmo no núcleo devoto, poucas mulheres tiram o pai-nosso e os benditos. Dessas, apenas algumas conseguem pegar a toada. Para as que não alcançam determinadas toadas, Didé estabelece toadas individuais. A correta execução das toadas mais puxadas são índices do conhecimento pleno da ciência da reza. No ritual, elas surgem, por exemplo, como elemento de disputa entre Zé e Didé. Na primeira vez em que o vi no terno, semanas depois do início da quaresma, Zé pareceu obstinado em mostrar que sabia rezar, pegando sempre a matraca e tirando vários benditos. Entretanto, Zé parecia ignorar tanto a condução das toadas como uma regra implícita, a qual rege que a mesma pessoa não pode tirar o pai nosso em mais de uma estação:

Eu sempre tiro aquela toada pra Idene [do núcleo devoto], porque nas outras ela muda, ela fica sem aprumar. Mas têm uns que não tiram na mesma toada não. Eu acho que isso atrapalha, viu. Eu acho que atrapalha porque tem hora que eu quero tirar uma toada, mas não consigo, aquilo foge. Outra hora eu quero uma, quando eu vejo eu estou tirando é outra. Muitas vezes você fica com aquela toada na cabeça, você tira e outro vai lá e... entendeu? E é por isso que quando eu sei que eles gostam de tirar em uma eu já tiro na intenção daquela pessoa ir, porque se ele tira naquela, ele não vão mudar. Só que têm uns, o Zé mesmo, ele tira em umas, aí eu já tiro uma porque eu sei que ele gosta de ir, só que tem hora que ele vai lá e muda. 
Partindo de duas realidades bastante diferentes, em um esforço comparativo entre o ritual de lamentação na Grécia e no interior baiano, é possível aludir a uma afirmativa de Caraveli-Chaves (1980) para pensar acerca das toadas como individualizações de estilo que compõem o caráter mágico da lamentação. Para a autora, esse caráter está diretamente ligado aos componentes idiossincráticos de cada indivíduo na execução do canto. Essa agenda de questões para o estudo da lamentação também está presente ao longo de várias formulações de Steven Feld $(1982,1990)$ sobre a relação entre as vozes nos cantos, a qual ganha contornos mais claros no tratamento que o autor dá à distinção entre polifonia e heterofonia:

How then to describe the relationship of the voices? This question cannot be answered merely by a technical musicological discussion. Since the voice relationships index the deeper issue of social relationships, which is to say the interplay of the individual and collective, personal and traditional dimensions of experience. (Feld, 1990:247).

No terno, as relações entre as vozes estão pautadas pelas toadas. Toadas são composições melódicas que desenham o corpo do som. São também elementos de devoção e organização das mulheres no rito e, algumas vezes, fora dele. Na classificação abaixo, temos três exemplos de toadas em grau de dificuldade crescente, sendo a primeira aquela que Didé tira preferencialmente para Idene, do núcleo devoto:

III. Bendito-louvado-seja

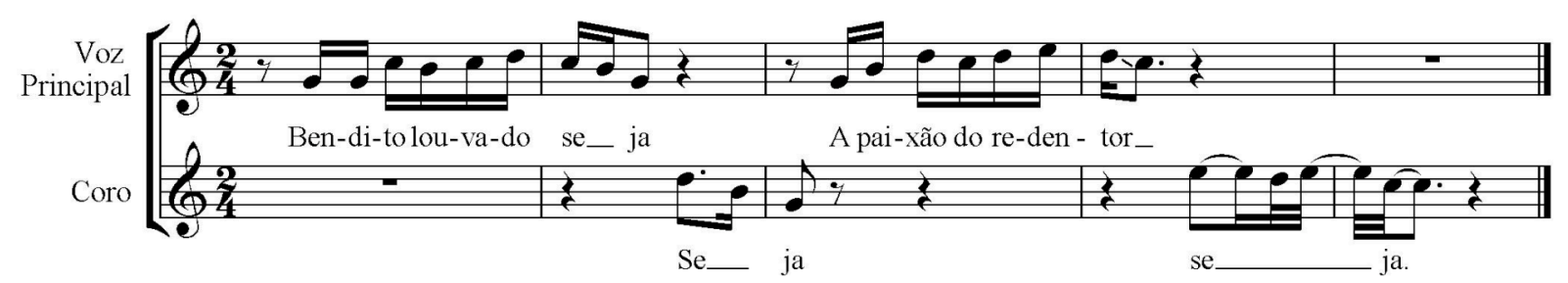

IV. Bendito-louvado-seja 

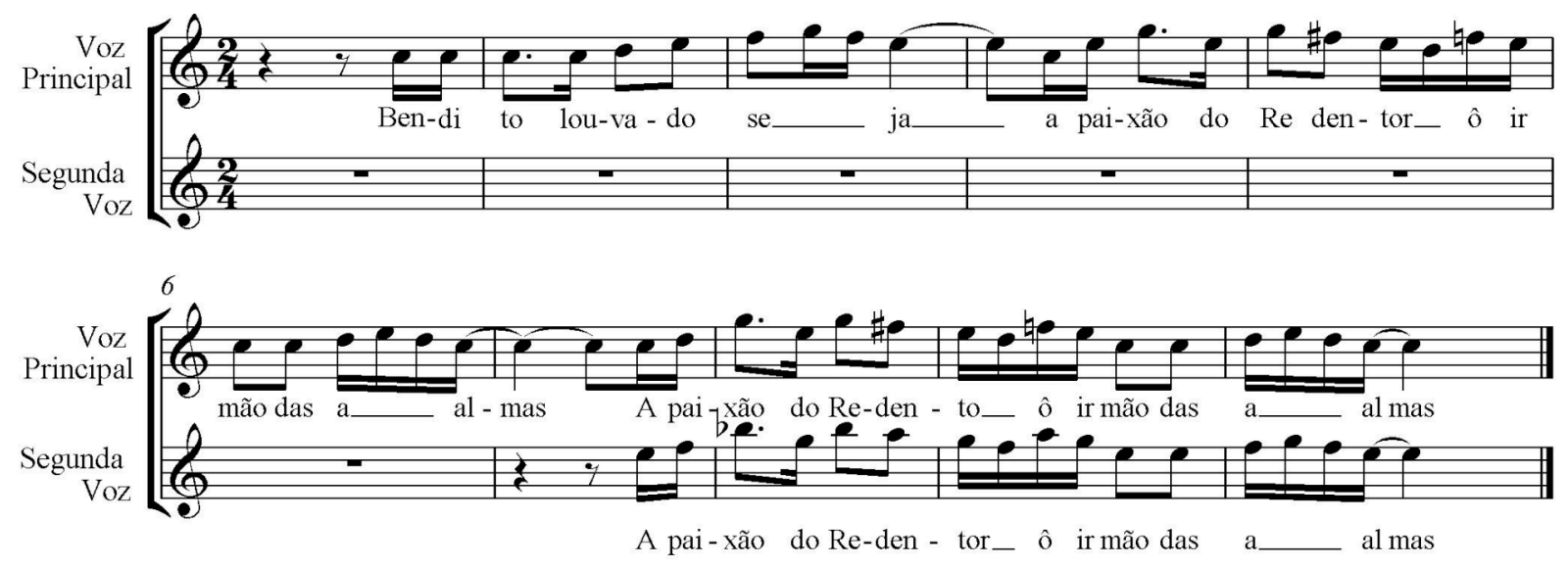

V. Bendito-louvado-seja

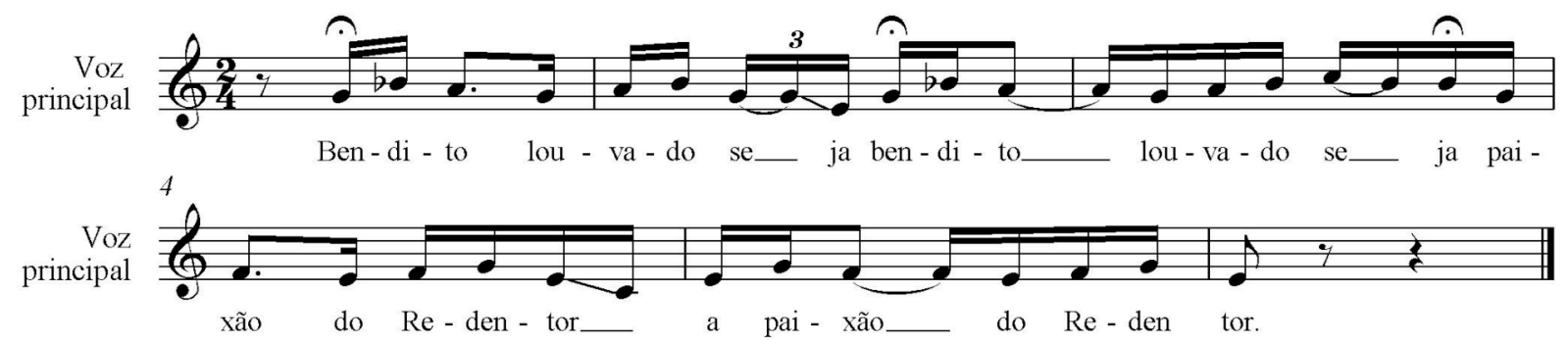

Nessa gradação, o bendito II transcrito anteriormente classifica-se no mesmo grau de dificuldade de IV. Essa categorização dos benditos foi apresentada por Didé em nossas conversas após algumas noites de saída do terno em Andaraí e diz respeito à soma do aprendizado ancestral à sua atualização no ritual. Por sua vez, a análise musical será feita com base na gradação no nível de dificuldade das toadas e representa a junção da musicologia nativa com as ferramentas da linguagem ocidental de notação musical. John Blacking nos alerta para a necessidade de tratar aquele que analisa um componente da estrutura do discurso musical como um agente tal qual se trata um compositor, performer ou ouvinte (Blacking, 1982:15). É importante lembrar, em primeiro lugar, que na teoria nativa os benditos não são música, mas dotados de elementos musicais, as toadas. A notação musical surge, portanto, como um mapa comparativo. O privilégio da análise recairá sobre o caráter dos símbolos musicais invocados no contexto ritual e não sobre uma visão musical do mundo ou de um sistema musical amplo.

Os recursos individuais da toada são definidos como mais ou menos puxados. O primeiro exemplo é descrito como o de mais fácil execução durante a reza. Sendo 
menos puxado, a transição do bendito para o pedido de pai-nosso/ave-maria torna-se menos sujeita a erros, em outros termos, a falhas de comunicação entre o mundo dos vivos e as almas. Como o alcance vocal de Idene possui pouca amplitude, apenas com esse bendito ela é capaz de aprumar: de seguir a regra da transição. A individualização também cumpre a função de manter o núcleo devoto atento ao momento da reza: “Quando eu tiro essa toada, ela já sabe que é a vez dela, porque ela tem boa vontade, mas ela não tem assim aquela tonalidade de seguir certo, para seguir a toada da música”. Nesse bendito, não há a segunda a voz de Miúda, apenas um coro que efetua o contra-canto. Nos três exemplos (e nos anteriores), a voz principal é transcrita a partir da voz de Didé. Vale notar que uma ou duas vozes tendem a acompanhá-la e, em alguns momentos, quase todas as outras vozes se juntam à voz principal, além de executarem o coro. Didé, contudo, não participa do coro nos benditos-louvado-seja. A mistura de vozes é uma de suas principais queixas quanto à execução dos benditos no ritual:

Ali na hora de tirar o pai-nosso, eu tiro e elas respondem. E às vezes uma ou duas podem me ajudar. Mas ali umas já fizeram furdúncio. Bendito também é melhor assim, vamos supor, duas ou três tiram e as outras respondem. Fica melhor, mais entoado.

O segundo exemplo é um bendito considerado de dificuldade mediana e rezado em todas as saídas, assim como o transcrito em II. Em sua execução, também ocorre a sobreposição das vozes na voz principal. O coro é praticamente inexistente, sobressaindo-se a segunda voz de Miúda. No bendito IV, encontramos as notas mais agudas dos três exemplos, todas entoadas por sua voz especializada. A ausência do coro traz prejuízos para o ritual. Segundo Didé, esse seria o momento em que as vozes deveriam se atualizar, isto é, entoar todas juntas uma resposta coral ao solo. As vozes desatualizadas impedem a comunicação fluida entre os mundos, além de esteticamente indesejadas pela dona do terno de Andaraí. No terceiro e último exemplo, contudo, a ausência do coro não é uma queixa de Didé. Nesse que é considerado um bendito muito puxado, há apenas a voz principal com quase nenhuma voz a acompanhá-la. Dado seu alto grau de dificuldade, a execução desse bendito é uma função praticamente exclusiva de Didé. É preciso ter uma extensão vocal maior para entoá-lo, pois o intervalo (de uma oitava) entre as notas mais graves e as notas mais agudas é o maior dentre os três benditos transcritos. Tal exclusividade reafirma o 
domínio da ciência da reza e coroa a liderança da dona do terno em detrimento das criticas das quais é alvo. O alcance vocal de Zé não permite que ele consiga, por exemplo, tirar o pai-nosso na mesma toada do bendito. As poucas rezadeiras que conseguem acompanhá-la nessa toada são Lôra, Miúda e Edite, todas do núcleo devoto.

Caraveli-Chaves (1980) define o lamento grego como "ponte entre mundos" (bridge between worlds). De forma semelhante, o vínculo efetuado por meio das toadas entre os vivos e os mortos não indica uma única direção. Pelas toadas, as almas também expressam a forma com que preferem receber as rezas, como explica Didé:

Às vezes eu estou aqui dizendo assim - "hoje eu vou fazer isso". Quando chega ali na hora eu não consigo lembrar aquilo que eu falei que ia fazer. Às vezes, eu estou pensando em tirar ali e na hora aquilo... parece que nada dá certo. Aí, para não perder tempo, tem que botar o que vem. E eu acho que é o que elas [as almas] querem também, né? Eu acho que é.

Na primeira vez em que Didé comentou acerca das toadas, eu ainda não havia acompanhado o terno. E mesmo quando comecei a rezar, demorei a entender a importância delas naquele cenário. Em parte, esse fato se deveu a uma confusão de categorias, pois Didé muitas vezes se referia às toadas como "tons" e era assim que eu as procurava na reza - e, fatalmente, não as encontrava. Foi preciso ouvir para além das categorias. A insistência de Didé em dizer que reza não é música, somada a minha lentidão em alcançar esse conceito, representou a necessidade de estabelecer outra relação com a palavra cantada.

\section{Benditos, preces e cantigas}

Falar de distinções entre música, palavra, canto e reza corresponde a pensar em quais categorias dão mais ou menos conta dos contextos em que os atos, pensamentos e sentimentos estão imersos. Não é uma distinção simples, como reservar o uso de uma ou outra a espaços seculares e sagrados. Alguns meandros dessa leitura chegaram até mim quando, pela primeira vez, fui convidada por Didé para ir ao jarê. No jarê da casa de Carmosa, o samba cantado é acompanhado de 
tambores, pequenas matracas, chocalhos de latas de óleo e muitas saias rodando. O samba é uma mistura de sagrado e profano, mundano e secular, o espaço das festas, da comida e das incorporações das entidades da casa. Alguns benditos, contudo, também são cantados no jarê - não no samba, mas nos trabalhos. De acordo com Didé, muitos dos benditos que são rezados no terno são também invocados quando, por exemplo, uma pessoa incorpora um espírito ruim. Ela explica que os benditos fortes são capazes de livrar pessoas em situações extremas, pois todos aqueles que fazem trabalhos, para o bem ou para o mal, são tributários das almas, pois são elas as regentes de processos terminais. Além dos benditos fortes, um dos elementos do terno, o Senhor Deus, é, conforme classifica Didé, a "última redenção" nos trabalhos do jarê:

Quando o trem está pesado, apela para as almas. [...] Em casa de macumba, quando eles fazem aqueles trabalhos que têm aquelas coisas que dão muito trabalho mesmo, o último que socorro é esse [Senhor Deus]. Eu mesmo nunca vi ainda nenhuma cena com ele nesses lugares. Mas eu já tenho na mente para os que fazem que o último socorro é ele.

O Senhor Deus, tanto no terno, quanto no jarê, é classificado como reza. Ainda que seja cantado, seu alto grau de força e especialização nos dois rituais realiza um tipo de comunicação exclusiva com as almas. O Senhor Deus também é rezado quando se morre alguém. Quando conversamos sobre o terno pela primeira vez, Didé citou o Senhor Deus e logo completou que não era certo sequer falar sobre essa reza fora de uma ocasião devida. Como explicado anteriormente, na reza das almas em Andaraí, o Senhor Deus é entoado no final das primeira e última estações. O certo, segundo Didé, é ajoelhar-se e tocar a cabeça no chão no momento dessa reza. Ninguém, contudo, realiza esse movimento. Em Andaraí, o texto do Senhor Deus é acrescido de algumas frases a parte de "Dai-nos, Senhor, uma boa morte" até a primeira série de "Senhor Deus, misericórdia". Essa parte foi incorporada ao texto por Didé que, tendo rezado com Bete, sentia falta dos versos que havia aprendido com sua mãe:

Letra, letra pecador

Hoje é vivo, amanhã morto

Nas escadas da sentença

Purgatório é penitência 
Aonde as almas vão penar

Dai-me, Senhor, uma boa morte

Dai-me, Senhor, o perdão

Dai-me, Senhor, uma boa morte

Pela vossa sagrada Paixão

Senhor Deus

Pequei, Senhor

Misericórdia

Senhor Deus

Misericórdia, misericórdia

Misericórdia

Senhor Deus

Pequei, Senhor

Misericórdia

Senhor Deus

Misericórdia, misericórdia

Misericórdia

Senhor Deus

Pequei, Senhor

Mas pela dor de sua mãe Maria Santíssima

Compadeceu, Jesus, das almas

Senhor Deus

Misericórdia, misericórdia

Misericórdia

Na macumba, os benditos e o Senhor Deus são rezados "na hora dura". Outro bendito rezado no terno e na macumba, é o "Maria Valei-me". Na segunda saída no terno em 2009, Didé tirou esse bendito, que também é rezado na Semana Santa, tendo em vista que o lugar em que estávamos rezando era muito pesado: um assassinato ocorrera ali anos atrás. Como princípio, os benditos fortes são rezados durante toda a Semana Santa. Em outras ocasiões contudo, possuem o poder de acalmar coisas que não estão dando certo (inclusive erros na execução das rezas e eventuais esquecimentos de alguns elementos do ritual, como a despedida), de enfrentar imprevistos, de apaziguar más energias, em suma, de aliviar situações em há qualquer tipo de atrapalhação. Existem duas versões de "Maria Valei-me", a do jarê, à qual não tive acesso, e a do terno - o Maria Vale-me "das almas" -, considerada a mais forte dos dois benditos:

Hoje nesse dia

Maria valei-me

Maria valei-me

Maria valei-me

Hoje no segundo dia Maria valei-me 
O benditos das almas jamais são rezados nas festas do jarê. A estrutura da festa é organizada pela saída e entrada das linhagens dos encantados - as entidades da casa e dos participantes do samba - e pela incorporação dos guias e das pessoas a ele/ela vinculadas. Para cada entrada e saída, existem cantos de chamada e despedida dos encantados (Senna, 1998:116). No jarê de Carmosa, os cantos são chamados de cantigas ou pontos. Na classificação nativa, a cantiga é música e serve para chamar o santo. Segundo Didé, alguns benditos também aparecem nas comemorações de alguns santos em forma de oferecimento e agradecimento pelas forças concedidas. $\mathrm{Na}$ festa de São Cosme e Damião (ou de Dois-Dois), por exemplo, dá-se o cariru/caruru durante o dia - é o começo do samba. Entre sete e oito horas da noite, faz-se um intervalo na festa e inicia-se a chamada ladainha, com preces (pai-nosso, ave-maria e salve-rainha) e rezas para as almas (como o Senhor Deus e Maria Valei-me). Logo depois, o samba recomeça com cantigas e incorporações.

Ao fundamentar a relação entre a força dos benditos e o chamado das almas, Didé amplia o uso de benditos para fora do momento do ritual do terno, lembrando que a própria noção de almas como dotadas de propriedades mágicas não se limita ao ritual de lamentação. As arestas costumeiramente estabelecidas quando observamos o uso dos benditos são insuficientes para dar conta dos muitos espaços e significados a eles atribuídos, pois benditos não estão restritos ao âmbito da devoção em manifestações do catolicismo popular. Em uma das conversas com Didé sobre suas experiências no jarê e sobre as consultas com curadores, fui instruída por ela a rezar benditos específicos em situações que envolvessem dificuldades pessoais e quando alguém conhecido incorporasse ou estivesse sob influência de um espírito maldoso. Esse fato me levou a perceber a linguagem do bendito como aberta, popular e compartilhada. Ao contrário da existência de textos secretos dos rituais de lamentação, observada por vários autores, inclusive por Elizabeth Tolbert (1990), a abrangência da eficácia dos benditos e a pluralidade de uso, tanto coletivo quanto individual, dá o tom de sua dimensão mágica. Nesse marco, o caráter mortuário das rezas e o peso do luto, tão presentes nos rituais do terno das almas, mesmo quando experimentam um deslocamento simbólico, preservam a validade de seus efeitos.

\section{Palavra falada e palavra cantada}


Temos ainda algumas questões analíticas que resvalam na instabilidade conceitual das categorias de canto e reza, fala e música. Acredito que algumas dessas questões passam pela pergunta feita por Stanley J. Tambiah, em The Magical Power of Words: qual é a base do poder mágico das palavras? (Tambiah, 1985:29). Vimos anteriormente que o texto musical é central para a eficácia da comunicação entre vivos e mortos no ritual, mas não se restringe a ele. Percebemos que, apesar de um ritual cujas origens remontam antigas tradições católicas, as raízes mágicas de suas práticas não permitem uma oposição entre cantigas/magia e rezas/religião. Como um ou como outro, os dois pares parecem empreender o mesmo tipo de comunicação com o divino, com as almas. A linguagem do ritual de lamentação, expressa nos benditos, não é diferente da linguagem ordinária, tendo como ponto de relevância no processo de comunicação o elemento musical. Nesse sentido, é preciso lembrar que o poder dos benditos não está ligado aos padrões musicais, mas aos textos, ao passo que o estabelecimento da comunicação é definido por meio dos recursos individuais da toada.

No ritual, entendido enquanto um sistema culturalmente construído de comunicação simbólica, a união entre forma e conteúdo é essencial para a realização de seu caráter performativo e de sua eficácia. A magia, como propõe Tambiah, adquire sentido no casamento entre resultados práticos e efeitos sociais. É importante salientar que não intento, na presente análise, restringir o ritual de lamentação a entoação de benditos. Foi, contudo, por meio da teoria nativa que a relevância crucial desses elementos veio à tona e tomou uma dimensão grandiosa na interpretação das rezadeiras e, por extensão, naquela aqui empreendida. Isso porque, quando entoado, o bendito intenta causar efeitos prescritos com base na crença em sua capacidade de efetuar a comunicação com as almas em territórios extramundanos. A união entre palavras, sentido, força convencional e efeito lembra as noções propostas por John Austin (1962) de força ilocucionária e de efeitos perlocucionários. Uma leitura possível sobre as relações entre dizer, chorar, rezar e cantar poderia, portanto, partir da reflexão acerca da teoria de atos de fala (speech acts) elaborada por esse autor.

Atos rituais são atos performativos e convencionais: a performance de um ato está orientada pelo quadro da ação social no qual ele se insere. Todavia, os efeitos, também convencionais, podem acontecer ou não. Isso significa dizer que o efeito perlocucionário esperado no proferimento de uma palavra/na feitura de uma ação, não invalida a sua dimensão performativa (Tambiah, 1985:135). Para Austin, o uso da 
linguagem como ação social emerge no ato de fala, por meio da correlação elocuções performativas e forças ilocucionárias. Nesse marco, a lamentação é uma tentativa de fazer algo com palavras e não apenas uma performance ritual em termos estilizados. De acordo com Austin, a enunciação de palavras, é, via de regra, o principal evento na performance de uma ação, mas está longe de ser o único evento necessário para o ato seja plenamente realizado. Deve haver uma série de circunstâncias específicas que garantam a enunciação das palavras, as quais, por sua vez, precisam ser apropriadas. Além disso, não apenas a pessoa que evoca, mas todas aquelas que se engajam na situação de proferimento, realizam outras ações, mentais ou físicas, e também a enunciação de palavras.

Existe uma ordem de condições, na teoria de Austin, para que o enunciado de palavras ocorra de modo satisfatório: tais procedimentos devem ser executados por pessoas que possuem determinadas crenças, sentimentos e intenções. Sem tais exigências, as pessoas engajadas nos atos em questão estarão cometendo um abuso do procedimento, o que significa dizer que haverá falta de sinceridade na enunciação nas palavras do autor, os enunciados serão "infelizes". Na lamentação das almas, podemos pensar que o idioma paralelístico dos benditos é um elemento da força ilocucionária que garante o efeito de alimentar as almas dos mortos, sendo mais ou menos feliz na gradação de poder presente no próprio texto musical. As toadas, na forma como foram definidas por Didé, estão submetidas a critérios de infelicidade e felicidade, ainda que na composição analítica, figurem como elementos não-verbais. Elas estão, contudo, afeitas a individualizações que levam em consideração o compartilhamento de uma crença e a participação em outras ações, como, por exemplo, nas disputas pelo conhecimento da ciência do terno.

A teoria dos atos de fala proposta por Austin permite ampliar a compreensão escopo de significação dos benditos na lamentação das almas. É preciso olhar e ouvir esse escopo dentro e para além do momento do ritual, ainda que este condense tantos símbolos e sentidos. Tambiah define ritual como um complexo de palavras e ações e pontua a necessidade de mostrar a interconexão entre elas. Para o autor, o objeto último dos rituais são as pessoas nele engajadas, as quais operam uma relação metafórica entre palavras e atos. Ao considerar que essa definição possui menos o caráter de limitação do que o de abrangência, a proposição de Tambiah nos ajuda a entender como a fronteira entre fala e música - entre os elementos verbais e não 
verbais no ritual de lamentação das almas - caminha para uma interpretação conjunta ao invés de uma separação rígida

[...] Is possible to argue that all ritual, whatever the idiom, is addressed to the human participants and uses a technique which attempts to restructure and integrate the minds and emotions of the actors. The technique combines verbal and nonverbal behavior and exploits their special properties. (idem:53).

Ao olhar para a presença dos benditos em situações fora dos ritos comuns ao terno das almas e ao perceber as relações entre as pessoas envolvidas no momento de sua enunciação, percebemos que a delimitação fixa das fronteiras entre música e fala carece de sentido. No lugar de separar as duas dimensões, a intenção do presente trabalho é aproximá-las, lembrando que os benditos, elemento central da reza das almas, encontram-se entre ambas. Segundo Ingold (2000), as palavras tornam-se significativas menos por via dos conceitos mentais que representam do que pela presença efetiva que criam e por seus usos situacionais. Na relação entre preces, cantigas e benditos, a linha diferenciadora parece se aproximar do tipo de ações que ensejam, quando comparadas aos conceitos às quais as três modalidades se referem. Entretanto, não se pode esquecer que qualidade de força de um bendito está diretamente ligada à sua função poética. A prioridade do texto desvincula o bendito da categoria de música na classificação nativa e a toada, por sua vez, o distancia do pólo da fala. Com base em um diagrama proposto por Antony Seeger (1987) que organiza as diferentes artes vocais dos Suyá (Kinsêdjê), temos as modalidades de canto e reza nos termos em que são caracterizadas no universo do terno e do jarê:

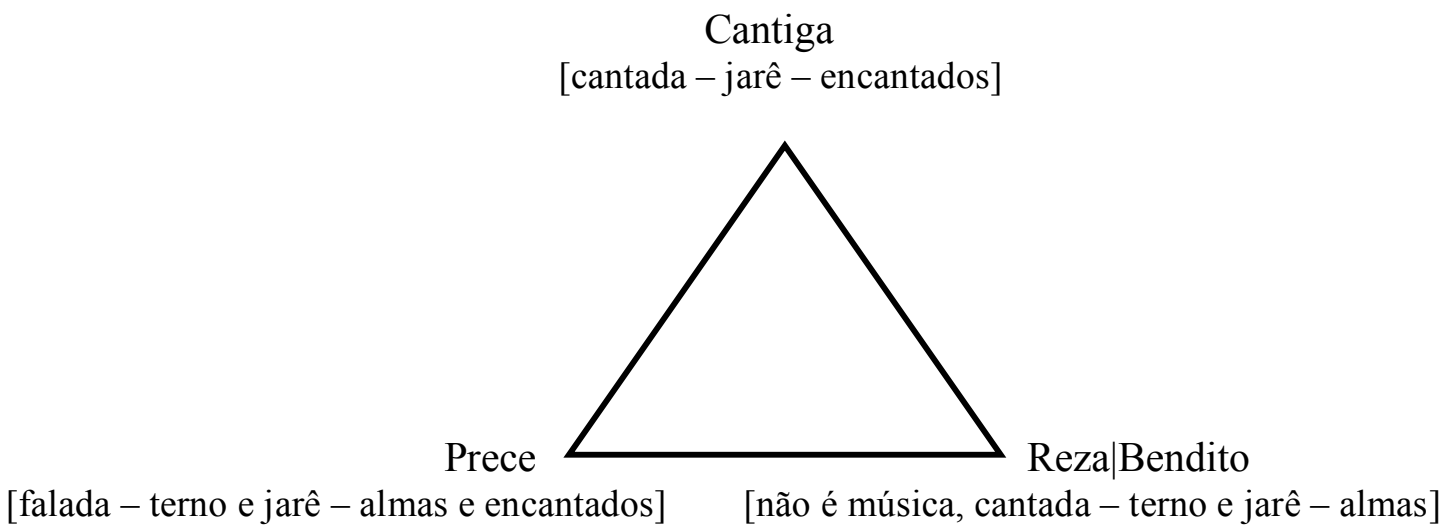

Figura 1. Modalidades de reza e canto 
Seeger propõe que pensemos o canto no contínuo de vocalização que indica o grau de formalização na arte vocal Suyá. No esquema do autor, o canto estaria mais próximo do pólo das performances altamente formalizadas musical e textualmente. Para realizar essa divisão, Seeger é guiado pela origem e pela composição da música e por como ela se relaciona com outros aspectos das vida e do cosmos dos Suyá (Seeger, 1987:51-2). Com o intuito de estabelecermos um contínuo entre fala e canto a partir da análise proposta por Seeger, recortaremos apenas os elementos que apontam para a relação entre texto e melodia, desconsiderando o grau de formalização ritual como chave para a análise comparativa entre as modalidades prece, bendito e cantiga:

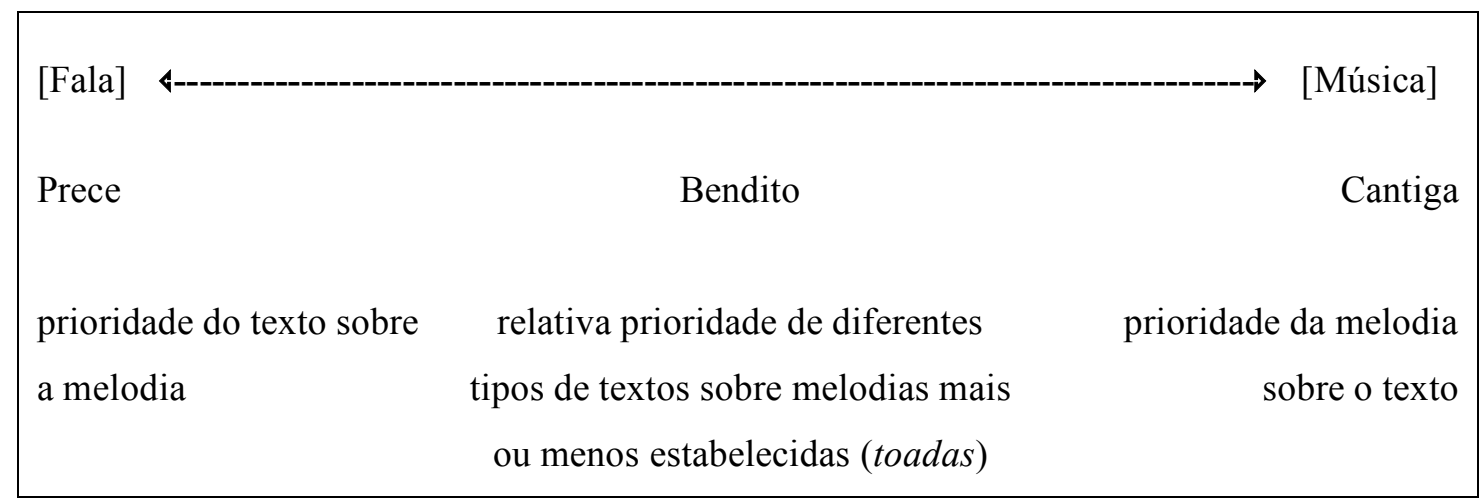

Figura 2. Modalidades no contínuo entre fala e música

A visualização gráfica da relação entre as modalidades nos ajuda a entender como o conceito de "reza" aparece do contínuo entre fala e música no sistema de categorização nativa. É importante pontuar, contudo, que os pólos desse contínuo não correspondem a uma divisão dual que separa cognição e afeto. Ingold (2000) chama a atenção para a necessidade de se exortar as ações de cantar como ligadas ao pólo emocional e sentimental e as de falar, àquele que se define como proposicional e intencional, concepções correntes na história da filosofia ocidental. Ao discutir sobre a validade etnográfica da noção de um contínuo entre fala (speech) e música (song), Blacking (1982), critica a idéia de que essa gradação possa advir de uma diferença no grau de formalização, como se um dos dois pólos, enquanto códigos, fossem mais ou menos restritos e/ou pertencente a diferentes sistemas cognitivos. No presente trabalho, a tentativa de aproximar dois pontos do contínuo parte muito mais das falas 
colhidas em campo acerca das modalidades do que de definições abstratas de fala e música na literatura etnomusicológica.

\section{Algumas considerações sobre a relação entre terno e jarê}

Nessa seção, será apresentado um pequeno esboço da profunda relação entre o terno e o jarê em Andaraí. No início da pesquisa, o jarê não figurava como objeto primário de atenção. Aos poucos, entretanto, ele foi trazido à cena pelas mãos de algumas das mulheres que rezam no terno e especialmente por Didé. Didé conheceu muitos curadores ao longo de sua vida, mas diz acreditar em poucos deles. Possui, inclusive, vários métodos para saber quais deles falam a verdade e quais apenas blefam. Ela não acredita que atar-se a uma pessoa ou credo irá ajudá-la em sua busca espiritual. Quando muito, vai ao jarê sambar e ajuda em alguns trabalhos, fugindo quando a designam a uma responsabilidade maior.

Antes de falar sobre as parecenças, é importante ressaltar que as duas manifestações são encaradas pelas mulheres que sambam e rezam como bastante sendo diferentes entre si, como explica Lôra - "Quem vai pra festa, vai pra festa. O terno é penitência.". O vínculo entre elas está dado pela premissa do tributo que se deve prestar às almas. Na Figura 4, podemos observar o tipo de comunicação efetuado por cada modalidade e atestar a presença do jarê nos três vértices do triângulo. É principalmente na figura do curador de jarê que essa afinidade se materializa. Segundo Didé, os curadores de jarês devem acompanhar as saídas do terno. $\mathrm{Na}$ quaresma de 2009, Carmosa rezou todos os dias da Semana Santa. Zé da Bastiana, o curador mais famoso de Andaraí, falecido em 1984, morou na Piranha e saía no terno da mãe de Didé antes de se consagrar com os trabalhos e sambas que realizava em seu chalé

Esses negócios de reza têm muitas coisas ligadas. Porque esses que trabalham em candomblé não fazem nada sem elas. Sabia que eles todos dependem das almas? Eles todos dependem. Às vezes, tem uns que não dizem, mas não tem um que não trabalha ali que não precisa delas. Sem elas, eles não são ninguém. Primeiro porque um espírito, de qualquer maneira, foi morto. Não tem jeito. Tem espírito bom, tem o ruim, tem tudo, porque a vida é assim, cheia de bom e de ruim. Mas de qualquer maneira, se ele é espírito, ele foi morto. As coisas são todas ligadas. Aqui mesmo tinha um curador que tinha um chalé aqui, você já viu? Um casarão aqui para cima. Têm uns vinte e tantos anos que ele morreu e ninguém nunca abriu lá, não fez nada. Zé da 
Bastiana, ele era muito famoso. Ela ia lá no terno na Piranha [zona rural de Andaraí] onde a gente morava, ele saía todo ano quase.

Há, por certo, uma diferença entre os espíritos dos encantados e as almas. Ambos, porém, partilham da condição de pessoas mortas que um dia habitaram o mundo dos vivos. Como explicam Paulo Alves e Miriam Rabelo, na cosmologia do jarê, "o indivíduo está continuamente interagindo com pessoas, espíritos e coisas que não pode controlar e dos quais sabe muito pouco" (Alves e Rabelo, 2009:6). O jarê não pressupõe o controle do conhecimento sobre os encantados por parte de um especialista - o curador. Não há aprendizagem formal, mas um contato aberto com os procedimentos do ritual e uma vivência intensa e prematura nos terreiros. Sua iniciação, via de regra se dá na forma de transes domésticos, quase sempre interpretados, em um primeiro momento, como desvios mentais. Mesmo que uma pessoa freqüente um determinado terreiro com regularidade, é comum que se negue a realizar o trabalho para lidar com as incorporações e cumprir com as obrigações do santo. Segundo Didé, o indivíduo que começa o trabalho no jarê não pode abandonálo, pois será incomodado pelo encantado até que passe a atender seus pedidos. Ainda que essa seja a regra, quase ninguém a cumpre. Nas palavras de Ronaldo de Salles Senna, o transe

Identifica o jarê, no tempo e no espaço social onde opera, com uma engrenagem acionada pelos espíritos para funcionar a contento e encaminhar soluções para problemas imediatos. (Senna, 1998:180).

Uma das feições do transe no jarê é a radiação. Em algumas situações, o caboclo pode não tomar toda a mente daquele que o incorpora. Isso acontece principalmente quando a pessoa inicia o trabalho na casa, mas ocorre com alguma freqüência com o próprio curador. A radiação do caboclo é uma espécie de cochicho do encantado: ele encosta na pessoa, manipulando-a silenciosamente. Foi Didé quem definiu as possíveis incorporações no terno das almas. Logo nas primeiras conversas, Didé era resoluta em afirmar que ninguém pegava caboclo na reza. Na minha segunda ida ao jarê de Carmosa, no mês de novembro, havia uma moça bastante jovem iniciando um trabalho, depois de ter passado semanas internada em uma clínica psiquiátrica em Salvador. No samba, a jovem, sob efeito da radiação, ficou radiada. Ao contrário de Maurina, Carmosa e outras pessoas que estavam na casa naquela noite, ela não incorporava um ou outro caboclo específico. Ela sambou em todas as 
cantigas, como se estivesse pegada ou incorporada, mas sem uma manifestação particular. No dia seguinte, Didé me explicou que aquele era o fenômeno da radiação no samba e que no terno, com algumas alterações, ele podia acontecer. A ausência da cantiga do ritual de lamentação é o impeditivo para que a incorporação aconteça de forma total. Além disso, as almas não aceitam bagunça ou folia dentro de sua reza. Todavia, por estarem em contínua comunicação com os espíritos, muitas mulheres ficam radiadas de forma praticamente imperceptível.

Apresentamos, ao fim desse texto, algumas convergências entre o bendito no ritual de lamentação e as cantigas do jarê em Andaraí. Isso porque somente com base em uma análise da estrutura do jarê e de sua ciência seria possível estabelecer um diálogo mais sólido entre as duas manifestações. Até aqui, a intenção foi desvelar pontos de tangência que surgiram ao longo do trabalho de campo. A função e classificação das cantigas, a importância das almas e o fenômeno da radiação são apenas linhas de um complexo campo de religiosidades ao qual nos aproximamos pelas lentes do ritual. A intenção foi percorrer algumas dessas linhas, cerzindo alguns desses pontos. Muitos enleios, os mais profundos, porém, permanecem entrelaçados nas tramas delicadas de um mundo que não se alcança com os olhos do método.

\section{Referências}

ALEXIOU, Margaret. 1974. The Ritual Lament in Greek Tradition. Cambridge: Cambridge University Press.

ALVES, Paulo César e RABELO, Miriam Cristina. 2009. Jarê: Religião e Terapia no Candomblé de Caboclo. In: Anais do Encontro de Estudos Multidisciplinares em Cultura. Salvador: Faculdade de Comunicação/UFBA.

AUSTIN, John L. 1962. How to Do Things with Words. New York: Oxford University Press.

BIANCARDI, Emília. 2006. Raízes musicais da Bahia. Salvador: Omar G.

BLACKING, John. 1982. The Structure of Musical Discourse: The Problem of the Song Text. In: Yearbook for Traditional Music 14: 15-24.

BRIGGS, Charles. 1992. Since I am a Woman I Will Chastise my Relatives: Gender, Reported Speech, and the (Re)production of Social Relations in Warao Ritual Wailing. In: American Ethnologist 19 (2): 337-61.

CAMPOS, Roberta Bivar Carneiro. 2008. Como Juazeiro do Norte se tornou a terra da Mãe de Deus: penitência, ethos de misericórdia e identidade do lugar. In: Religião e Sociedade [online] 28(1): 146-175.

CARAVELI-CHAVES, Anna. 1980. Bridge Between Worlds: The Greek Woman's Lament as Communicative Event. In: Journal of American Folklore 93:129-157.

CARVALHO, José Jorge de (org.). 1996. O Quilombo do Rio das Rãs: Histórias, Tradições e Lutas. Salvador: EDUFBA.

CUNHA, Roberto. 2002. Um Rio São Muitos. Tese - Universidade de Brasília. Programa de Pós-Graduação em Antropologia Social. 
FELD, Steven. 1982. Sound and Sentiment: Birds, Weeping, Poetics, and Song in Kaluli Expression. Philadelphia: University of Pennsylvania Press.

1990. Wept Thoughts: The Voices of Kaluli Memories. In: Oral Tradition 5 (2-3): 241-66.

e FOX, Aaron. 1994. Music and Language. In: Annual Review of

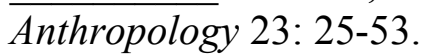

INGOLD, Tim. 2000. The poetics of tool use: from technology, language and intelligence to craft, song, and imagination. In: The Perception of the Environment: Essays on Livelihood, Dwelling \& Skill. London: Routledge.

JAKOBSON, Roman. 1971. Closing statement: Linguistics and poetics. In: Selected Writings Vol. 2. New York: Mouton.

LYSAGHT, Patricia. 1997. 'Caoineadh os Cionn Coirp': The Lament for the Dead in Ireland. In: Folklore 108: 65-82

MAUSS, Marcel. 2003. Esboço de uma teoria geral da magia. In: Sociologia e Antropologia. São Paulo: Cosac \& Naify [Originalmente publicado em L'Année Sociologique, 1902-1903, em colaboração com H. Hubert]

NEVES, Guilherme Santos. 2008. Coletânea de estudos e registros do folclore capixaba: 1944-1982. Vitória: Centro Cultural de Estudos e Pesquisas do Espírito Santo.

PIERSON, Donald. 1972. O Homem no Vale do São Francisco. Tomo III. Rio de Janeiro: SUVALE/Ministério do Interior.

REIS, João José. 2009. A morte é uma festa: ritos fúnebres e revolta popular no Brasil do século XIX. São Paulo: Companhia das Letras.

SEEGER, Antony. 1987. Why Suyá Sing: A Musical Anthropology of an Amazonian People. Cambridge: Cambridge University Press.

SENNA, Ronaldo de Salles. 1998. Jarê: Uma Face do Candomblé. Feira de Santana: UEFS.

TAMBIAH, Stanley J. 1985. Culture, Thought, and Social Action. An Anthropological Perspective. Cambridge, Mass.: Harvard University Press.

TOLBERT, Elizabeth. 1990. Magico-Religious Power and Gender in the Karelian Lament. In: Herndon, M. e Ziegler, S. (eds.). Music, Gender and Culture. Wilhelmshaven: Florian Noetzel.

URBAN, Greg. 1998. Discourse, Affect, and Social Order: Ritual Wailing in Amerindian Brazil. In: American Anthropologist 90 (2): 385-400. 